\title{
CHINESE INVESTMENT AND ITS IMPLICATIONS FOR NIGERIA'S ECONOMIC SECURITY
}

\author{
Shiitu Adewole Raji ${ }^{1}$ \\ Adenike Ogunrinu ${ }^{2}$
}

\section{Introduction}

The international system consists of different nations which pursue their national interests within the global arena having put into consideration the benefits they stand to gain from such relationships (Ampiah and Sanusha 20I5, 8). The explosive growth of China's economic interests in Africa, which is part of the sustained global interactions discussed above, is an important trend in the continent's foreign relations arena. China's rapidly expanding ties with Africa has superseded the United States' since 20I0 as Africa's top trading partner because of its massive investments in the continent, which is largely aided by China Investible Export loan assistance of \$150 billion to its multinational corporations (Brautigam 2009, 22). Between $200 \mathrm{I}$ and 20II, Chinese exports to Africa were raised from $\$ 4.4$ billion to $\$ 56.3$ billion. Though China is still regarded as a third world country, the country is the second biggest economy in the world.

Over the years, China has been relating to Nigeria through trade, aid and investments while Nigeria has equally be exploring trading opportunities in China. The Sino-Nigeria relation also has its basis on the premise of exploring their economic comparative advantages for mutual benefits. The Sino-Nigeria trade has also increased as China's growing economy requires more raw material resources from Nigeria; including crude oil to propel its industries. China is also taking advantage of Nigeria's huge population, which is estimated at around I5O million people (Nigeria Population Census 2006, I) to generate extraterritorial

I Centre for Peace and Strategic Studies, University of Ilorin, Ilorin, Nigeria. E-mail: adraj20ıo@yahoo.com

2 Centre for Peace and Strategic Studies, University of Ilorin, Ilorin, Nigeria. 
markets for China's manufactured goods. Due to its huge population, the most populous country in Africa, rich in natural resources, Chinese investments in Nigeria have become a trending issue in the $2 \mathrm{I}^{\text {st }}$ century as more than 200 Chinese companies are currently operating in Nigeria, thus making the country the largest recipient of Chinese Foreign Direct Investment (FDI) - about \$I5 billion out of its $\$ 26.5$ billion investments in Africa as of 2016 .

In spite of the functional relationship between Nigeria and China, the benefits from the socio-economic interaction between the two countries have been subjected to diverse opinions by scholars and analysts, in which Chinese investments in Nigeria attracted resentment and criticisms. Concerns have been raised specifically over the impact of Chinese investments in Nigeria's economic security, which is substantially affected by the dumping of inferior Chinese industrial products into the country, lack of technology transfer from China to Nigeria, fewer opportunities for the survival of Nigeria's investments in China, visa and employment restrictions to Nigerians to explore business opportunities in the country (Ogunsanwo 2018, I2).

Enuka (20IO, II) also argues that the FDI from China has heightened Nigeria's dependence on the Chinese economy, thus undermining its own economic security. This paper investigates the implications of the NigeriaChina bilateral relations for the economic security of Nigeria. Specifically, the paper traces the background of the Nigeria-China relations, examines the main thrusts and strategic importance of the relationship. The study also identifies the key sectors of Chinese investments in the Nigerian economy and discusses the implications of their relationship for the Nigerian economy.

Although there is a vast body of literature on the bilateral relations between Nigeria and China, little is known about the implications of China's increasing FDI for the economic security of Nigeria, a gap this paper intends to fill. The study is anchored on descriptive research methodology, consisting of qualitative data, which relied primarily on the existing literature.

\section{Operational definition of terms}

Investment: is the allocation of the present wealth; wholly or partly with the hope of reaping benefits in form of return or profit, either in cash or kind immediately or in future.

Economic Security: as used in this paper is the state of economic maturity which is characterized by economic growth and exponential development to the highest level without any threat of internal and external 
strangulation. Such secured economy is transformed from its nascent stage to maturity through the input of highly skilled human resources and policies sufficient for functional and sustainable political economy that is self-sustaining without any negative external economic interference. It is an advanced and independent economy that is sufficient enough for national and personal development aspirations of the citizens without any internal and external setbacks or threat of strangulation.

\section{Review of Literature}

As opines Ogunsanwo $(2008,6)$, Chinese investments and aid in Africa, which have risen from \$9.68 billion in 2000 to \$I.3 trillion in 2013, are a tool for exploiting African resources by China in the $2 \mathrm{I}^{\text {st }}$ century, because such exponential rise in China investments has doubled the amount of both legally and illegally repatriated profits from Africa to China, while a meager I5 percent of the profits have been paid as taxes in the continent between 2006 and 2013. The World Investment Report (2012, I7) submits that China's FDI inflow to West Africa is mainly dominated by Nigeria, which received 70 percent of the $\$ 87$ billion sub-regional total and II percent of Africa's \$1.3 trillion investment total. Out of this amount Nigeria's oil sector alone received about 80 percent of the China FDI inflow into the country. As noted by the report, even though the huge Chinese investments in Africa ought to be mutually beneficial to both parties, especially in the area of technology transfer and equal opportunities for market access, many African countries are still dependent on China for their industrial import in exchange for their low value primary produce, which has tilted the scale of both the balance of trade and balance of payment in favor of China. Pease (2OIO, 2I) posits that the relationship between Africa and China is not a recent development as the People's Republic of China has been providing aid to African nations since the early I950s, beginning with a loan of about \$2 million to Egypt in I956, while China also has provided aid packages to most African countries that recognized the 'One-China'. Ogunrinu $(2017,9)$ argues that since the Chinese government initiated the "Go global" strategy for capturing global markets through both public and private Chinese enterprises in I998, its FDI has been increasing in Africa through its investment strategies in the continent, which center on building the necessary infrastructure to explore African oil and gas for China's industrial growth.

Mthembu (2009, 2-I3) contends that, contrary to the allusion that the FDI from China has not contributed to the development of Africa, much 
of such investments have remained a catalyst for promoting infrastructure development, employment generation and revenue generation in the continent through payment of taxes by Chinese industries operating in Africa, while also contributing to its Gross Domestic Product aggregates. As noted by the author, the breakdown of the trade relations between China and Africa shows that Nigeria has had \$I5.42 billion net investments from China, Algeria \$9.23 billion, South Africa $\$ 6.64$ billion, Democratic Republic of Congo $\$ 6.55$ billion, Niger $\$ 5.26$ billion, Egypt $\$ 3.23$ billion, Libya $\$ 2.28$ billion, Zambia $\$ 2.49$ billion, Sudan $\$ 2.2$ Io billion, Ethiopia \$1.9 billion, among others. A critical check on this trade relationship shows imbalance of trade to the disfavor of African countries that exchanges their low valueadded products at far lesser prices with industrial products from China with higher foreign exchange earnings for the latter.

The World Bank, in its report (20I4, 6), criticizes China's lending conditionality to Africa as the Bank argues that the generosity of the Chinese aid programs, its low-interest loans, unconditional debt relief program undermine the efforts of global financial institutions to foster good political and economic governance in Africa, while also undermining the influence of the financial outlets in Africa. In Angola, for example, after the Export-Import Bank of China provided \$2 billion loans and credits with feeble repayment conditionality that borders on long moratorium, the Angolan government turned down a financing agreement with the IMF that included measures to strengthen transparency in the oil sector. Chinese Loans to the Sub-Saharan Africa exceeded that of the Western nations and by 2009, 35 African countries had their debts canceled by China, amounting to approximately \$30 billion. It was also reported by the author that between 200I-20I0, China Exim bank loans to Sub-Saharan Africa for infrastructure development reached $\$ 67.2$ billion, overtaking the World Bank lending of US\$ 54.7 billion.

Ian $(2006,27)$ located the core interests of the China-Nigeria relations in the area of trade and industry, in which Nigeria gave generous concessions to the Chinese to establish industries in the country. The author also discussed the contemporary drivers of the relationship between the two countries, which revolves around Nigeria's oil in return for China's aid. Despite Ian's attempt to chronicle the major events that occurred in Nigeria-China relations, the work did not exhaust other vital areas of the bilateral relations such as the condition of service of the Nigerian workers in Chinese industries, among others.

Jiang (2009, 25-28) describes the Nigeria-China relations from the economic sphere as the most important aspect of their relationship, which has paved way for huge Chinese investments in Nigeria to the tune of about $\$ 46$ 
billion. However, his work was silent on the resentment of Nigeria against Chinese industrial products, which many Nigerians consider as substandard. Another relevant academic position on Nigeria-China bilateral relation was provided by Oniku and Gbadamosi $(2009,2)$ where they examined the evolution of trade and diplomatic ties between leading African countries, including the one between Nigeria and China, particularly from I999 to 2007 . Their work revealed that China has benefited more from the bilateral relations between it and Nigeria, having repatriated more than $\$ 84$ billion from Nigeria between I997 and 2007, while Nigeria's non state actors repatriated less than \$Io billion profits from China in the same period. Besides that, there is the issue of trade imbalance and huge Chinese loans that are gradually sinking Nigeria into an abyss of debt. As argues Davies Martyn in his book: Special Economic Zones: China's Development Model Comes to Africa, the precarious trend of Chinese debt overhand by Nigeria, if not speedily checked, will eventually allow China to condition the economic export and import direction of Nigeria in favor of China.

The Nigeria Labour Congress $(2016,5)$ criticizes Chinese firms in Nigeria for being "closed" as they hardly employ highly skilled local experts. As posits the Union, the conditions of employment of Nigerians in Chinese firms neither conform with the Nigerian Labour Laws nor to that of the International Labour Organisation (ILO). The Union equally contends that technology transfer from Chinese FDI to Nigeria is insignificant because most of the Chinese firms bring into the country finished products and complete the equipment with Chinese technicians.

However, the quest for oil and gas by the Chinese seems to be of importance in the resurgence of the current wave of relations. Consequently, Chinese nationals are not immune to the spate of social unrest in the Niger Delta; the area where oil and gas are located in Nigeria. Some of the Chinese oil workers have been abducted by the militants, who are agitating for a more equitable distribution of resources in the country. Despite the limitations identified in the above works on Nigeria, they are useful for a clear understanding of the origin of the bilateral relations between Nigeria and China as well as the nature and dimension of such relationship.

\section{Theoretical Framework}

This paper adopts both the Cooperation and the Dependency theories as its frameworks of analysis. Within the confines of the theory of cooperation, 
Joseph Nye and Robert Keohane (I994) have argued that international relations are characterized more by cooperation and interdependence of nations with win-win, mutually benefiting outcomes. What this means is that both weak and strong economies have something to gain in a relationship, no matter the proportion, while the dynamics of unequal relations in the international division of labor cannot be ignored. Dependency theory is a social science tool of explanation that is predicated on the notion that resources flow from a "periphery" of poor and underdeveloped states to "core" wealthy states, enriching the latter at the expense of the former.

Dependency theory originates from two papers published in I949one by Hans Singer, the other by Raul Prebisch - in which the authors observe that the terms of trade for underdeveloped countries, relative to the developed, had deteriorated overtime because of the exploitative nature of the relationship between the two worlds. The theory arose as a reaction to the modernization theory; an earlier theory of development, which held that all societies progress through similar stages of development and that today's underdeveloped areas are thus in a similar situation to that of today's developed areas sometime in the past, and that the best strategies to bail the underdeveloped countries out of poverty is to accelerate them along this supposed path of development shared with the West through acceptance of foreign direct investment, technology transfer and closer integration into the world market. Dependency theorists rejected this view and rather opined that what is causing the underdevelopment in poor countries is the exploitative relationship that have characterized the interactions between the poor nations and the developed ones from the colonial times until our days. It is a central contention by the dependency theorists that poor states are impoverished and rich ones enriched by the disadvantaged way the former states are integrated into the world system. Dependency is thus a situation in which a certain group of countries has its economy conditioned by the development and expansion of another, in which the former is subservient. The main African proponents of dependency theory are Santos, Walter Rodney, Samir Amin, and Claude Ake.

Even though Nigeria and China have cooperated for mutual economic benefits, the relationship between Nigeria and China could better be explained within the dependency theoretical foundation, in which the trend of relations between the two countries favors China as the senior partner in the relationship, a position she has been using to condition Nigeria's development pattern to produce the raw materials needed for China's industrial growth in return for Nigeria's reliance on imported goods from China instead of producing its own, thus leading to balance of trade and balance of payment problems for Nigeria. The two theories of Cooperation and Dependency are very central to 
this paper because the central arguments from the two theories are that both weak and strong economies have something to gain in a relationship, no matter the proportion through functional and optimal cooperation, even though the dynamics of unequal relations in international division of labor cannot be ignored in such relationship because of the dependant nature of international politics.

\section{Historical background of Nigeria-China Relations}

Nigeria's first contact with China took place in I960 when a Chinese Delegation, on the invitation of the Nigerian government, attended Nigeria's independence celebrations (Ogunsanwo 20I8, 7). The delegation brought a message from Chinese leaders congratulating Nigeria on the victory won by the Nigerian people in their struggle against colonialism. In February, I97I, Nigeria finally established a diplomatic tie with China, more than a decade after independence. Both countries opened embassies in each other's capital within the year. Ever since then, the China-Nigeria bilateral relations have developed rather slowly over the years.

Right from the time General Gowon, who as military Head of State first paid an official visit to China in I972 to seek its financial assistance for the post-war reconstruction programs, shortly after the Nigerian civil war, in which China supported the Biafra (Pease 20I0, I3). General Abacha also supported China in the wake of the crackdown of Chinese political oppositions in Tiananmen Square, in Beijing, that led to China's international isolation in I977. The then Chinese premier, Li Peng, also visited Nigeria in I998 to boost China's renewed interest in the country, aimed at reversing the decline in China's trade with Nigeria (Reno I999, 6).

In 200I, Olusegun Obasanjo, the then Nigerian President, undertook a visit to China, primarily to woo China's industrialists to come and invest in the Nigerian economy ${ }^{8}$. The bilateral agreement reached between the two countries during the visit harped on economic agreements over the petroleum sector, which culminated in the active participation of Chinese firms in the upstream and downstream sector of Nigeria`s oil, gas and petrochemicals industries. In fact, Obasanjo offered the Right of First Refusal (RFR) on oil blocs to China at discounted rates in exchanged for their mandatory investments in the oil downstream and transportation sectors, especially in the areas of oil exploration and construction of roads and rail lines respectively. When an oil block bidding round was held in 2006, China`s National Petroleum Commission (CNPC) was awarded 4 oil blocs and 2 oil 
production licenses in return for China's commitment to invest \$2 billion to rehabilitate Kaduna's oiling refinery in Nigeria. There was also the Oil for Infrastructure exchange program between the two countries, where China was contracted for road and rail construction worth $\$ 5$ billion and collected crude oil equivalent to the cost.

Nigeria and China also established a strategic partnership in 2006 , which allows both countries' goods and services free access to each other's markets. The high degree of corruption in the bidding process for oil and poor or non-execution of projects by many Chinese investors led to the cancellation of the oil for infrastructure program and its replacement with Oil for Cash policies, which allows China to pay the equivalent cash of oil imported from Nigeria, while the oil infrastructure projects were executed under the publicprivate arrangement between Nigeria and some private enterprise in China, including the one between the Nigeria National Oil Corporation (NNPC), a Nigerian public enterprise in the oil sector, and the China State Construction Engineering Corporation (CSCEC). The two companies jointly executed a $\$ 23$ billion contract for the refurbishment of three Nigeria refineries and the construction of crude oil refined fuel complex, financed with $\$ 8$ billion by Sinosure and China Exim Bank. The CSCEC provided 80 percent of the costs, with NNPC releasing the remaining 20 percent counterpart funding. The Chinese Company also helped Nigeria build the NIGCOMSAT-I satellite that was launched in 2007.

Umar Musa Yar'Adua, who succeeded Obasanjo as President on the $29^{\text {th }}$ of May 2007 reviewed the 'oil for infrastructure' agreements between Nigeria and China, which led to the suspension of the contracts because the Chatham House report revealed that Nigeria lost up to $\$ 6$ billion in failed oil deals with China as no follow-up mechanisms to enforce the deals were put in place, leading to partial implementation or outright abandonment of many projects under the "Oil for Infrastructure" deal by Chinese investors in Nigeria.

Furthermore, the investigative committee's report revealed that much of the oil blocs were awarded to Chinese bidders who were well connected to the corridor of political power in Nigeria, but with little industry experience.

Though the Chinese requested the Yar'adua administration to sell a large number of oil and gas assets, estimated to contain six barrels of oil reserves, with an offer of $\$ 50$ billion as an alternative funding for infrastructural development in Nigeria, the government refused (This Day 20IO). The China Petroleum and Chemical Corporation (SINOPEC) equally bought Canada Addax, which was one of the largest oil producers in West Africa, with expansive offshore operations in Nigeria. 
During the Goodluck Jonathan Administration, Nigeria signed three loan agreements with China's Exim Bank. The agreement are the $\$ 500$ million for Abuja Light Rail Project, the \$500 million contract for the construction of 4 airports terminals in the country, and \$Ioo million contract for galaxy backbone expansion of connectivity among government ministries in Nigeria (NICAF, 20I3). The state visit of Goodluck Jonathan to the People's Republic of China in 20I3 expressed interest for over \$25 billion worth of investment by Chinese companies in Nigeria, including the $\$ 20$ billion Memorandum of Understanding signed between the Ministry of Energy in China and the Ministry of Energy, to generate for Nigeria 20,000 megawatts of electricity. China has also offered a $\$ 6$ billion loan to Nigeria for infrastructural development projects during the administration of Muhammadu Buhari and a loan of \$I.5 billion for the development of infrastructure in Nigeria, including the expansion of four airports at Lagos, Kano, Abuja and Port Harcourt, while the Buhari government also signed a currency swap agreement between Nigeria and China, in which the Nigeria' Naira is exchanged directly with China's yuan at their real value, instead of first converting them to dollar for their import and export business transaction. The effort has actually reduced the cost of importation from China to Nigeria and vice-versa, thus reducing the selling price of goods in both countries.

\section{The main thrusts and strategic importance of the Nigeria- China Relations}

There are eight core objective thrusts of the Nigeria-China bilateral relations (Ian 2006, II). They include guaranteed supply of raw mineral and agricultural materials for China in return for improved foreign exchange earnings for Nigeria, creation of a market for both Chinese and Nigerian products in each other's markets, obtaining land for agricultural purposes and gaining Nigeria's diplomatic support for China's interests in international affairs, in exchange for technical aid and loan facilities for Nigeria. Other foci of the China-Africa relations includes China's responsibility of presenting a credible alternative to the Western development model through foreign direct investment and teaching of the China development models, that largely rely on middle range technologies to Nigeria, unhindered migration of Chinese people to Nigeria and vice-versa. Another key thrust of the China-Nigeria relation is the provision of optimal information on possible investment opportunities in both countries and on how to seize such opportunities by means of conferences, lectures and other forums of discussion. 
The strategic relevance of the Nigeria-China bilateral relations to the two countries is quite overwhelming. Currently, China is the second largest economy in the world, an achievement she has successfully used to lift about 400 million Chinese out of poverty. This success has attracted attention from Nigeria, with its huge population, to learn lessons from China's experiences in the area of social protection, in order to be able to use its own poverty eradication programs to lift about 80 million Nigerians out of poverty. Nigeria is one of the countries blessed with the largest deposits of natural resources in Africa, which could aid China's industrial growth.

China is the most populous country in the world, with the fastest global economic growth in the last three decades, averaging Io\% annually, which has transformed it into a leading player in the global economy. Its national economy is now bigger than that of Japan, or the EU countries combined. Nigeria could learn from China how this economic feat was achieved and then replicate it in the country. Nigeria is the most populous country in Africa, with vast reserves of oil and gas, but the country needs China's financial and technical assistance to nurture these primary raw materials into value-added products that can earn Nigeria more foreign exchange in the international markets. China too needs Nigeria's oil and gas to propel its growing industry, while Nigeria is the largest market for China's industrial products in Africa, as the country's imports from China account for over a third of its total trade with West Africa.

The increasing diversification policy from exploration of oil to gas and other energy alternatives by the US and other Western states, which could affect the sales of Nigeria's oil resources to those countries, has brought about the need for the diversification of the exportation of Nigerian oil to China, with its greater potential of sustained patronage because of the tremendous increase of its key industries, that will continue to require Nigeria oil, which is within a million range. Increasing Chinese demand for oil from Nigeria has also made up for the slack in Nigeria's oil demand by the US, as China alone accounted for over $40 \%$ of Nigeria's global oil demand in 2017 . Thus, closer economic cooperation between Nigeria and China is very important for the sales of Nigerian oil. Nigeria is also seeking favorable external markets for its manufactured goods and services, which China could provide with its population of more than a billion people.

China's economy is heavily diversified, with high capacity to export various value-added products to many countries and generate huge foreign exchange in contrast to Nigeria, which is still over dependant on oil as the commanding height of its economy and weak source of foreign trade 
earnings. Nigeria could replicate the diversification templates from China for its economic growth. While China is the de facto leader of the developing world, Nigeria belongs to the African continent, with the largest number of developing countries that could be aided in cash and kind by China.

Nigeria, along many other African countries, also prefers to seek assistance from China, with soft loan conditionality compared the draconian loan conditionality of the Western countries. China is often willing to finance development projects in Nigeria, sometimes without collateral, a policy which many of its traditional partners from Europe refuse to adopt.

In spite of the benefits inherent to the bilateral relations between Nigeria and China and its strategic importance to both countries, there is anxiety and concern over the scale of China's activities in Nigeria, especially over its appetite for energy resources, that is bedeviled by poor environmental track record at home. The fear of possible environmental degradation from Chinese companies has raised concern among environmentalists in Nigeria about the implications of Chinese investments for environmental safety in the country. Consequently, Chinese investment is regarded as both a threat and opportunity for Nigeria.

\section{The key sectors of Chinese investments in Nigeria}

Positive investment relations have been recorded in the Nigeria-China bilateral relations. Available information points to a general upward trend in the inflow of FDI from China to Nigeria. Although, information about Chinese activities in Nigeria points to increasing socio-economic activities, trade, commerce and investment, health, education and technical relations, the bulk of Chinese investment in Nigeria is more pronounced in the economic sector. According to the East Asian Investment Indicator (20I6), China has set up over 200 solely-owned companies and joint-ventures in Nigeria, which are actively involved in the construction sector, oil and gas, technology services and education sectors of the Nigerian economy. Indeed, Chinese economic interests in Nigeria can be broadly classified into three, including those owned solely by private Chinese investors, those investments owned by the Chinese government, those jointly owned between Chinese and Nigerian private investors and those privately owned between Chinese and other foreign investors. Chinese investments have also benefited from the Nigerian incentives to foreign investments, including tax breaks and generous expatriation quotas. Table 3 below showcases the Chinese investment pattern in Nigeria. 


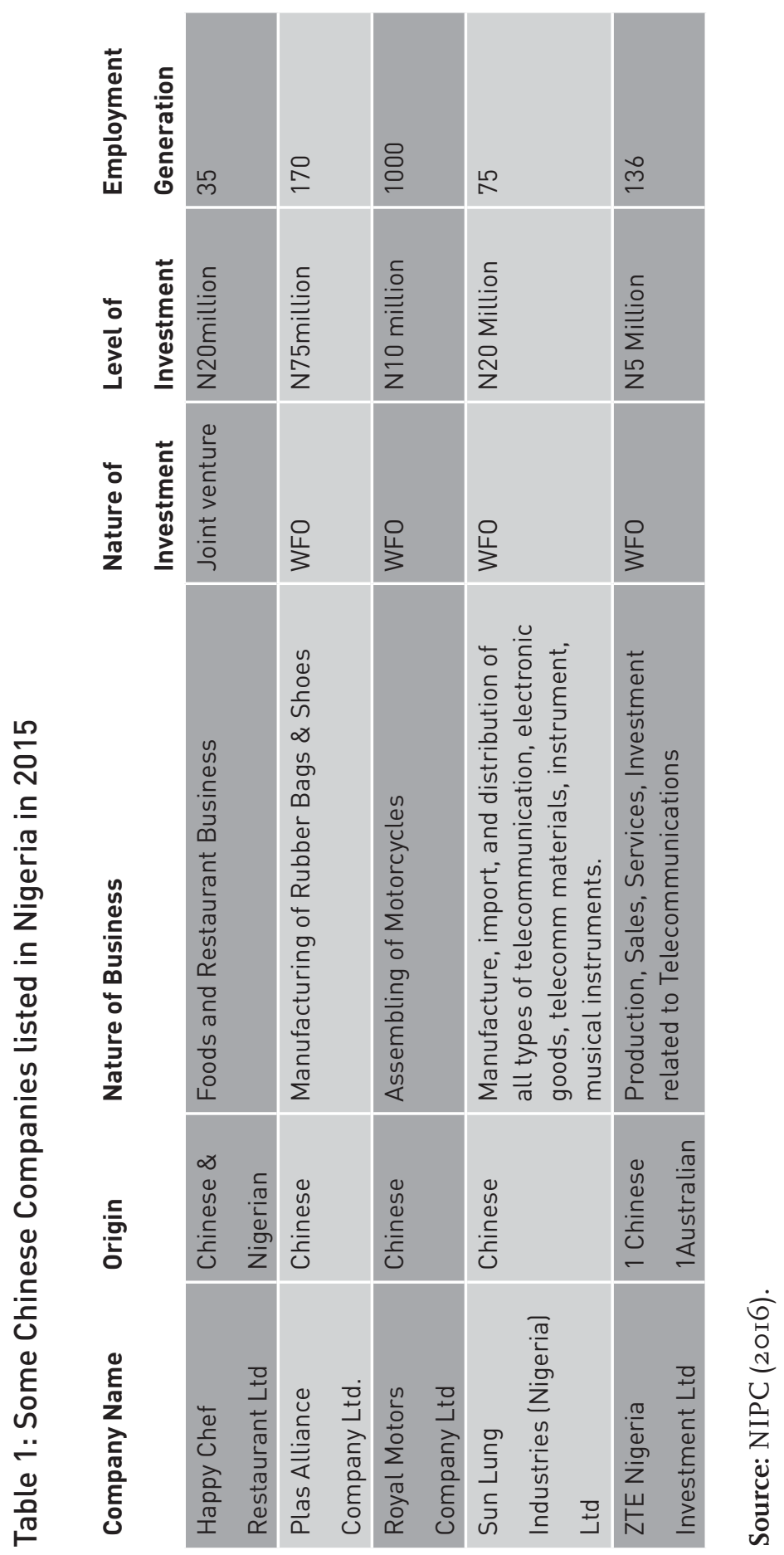


Conversely, Nigeria's exports to China are spread over many and varied products, which have been classified according to the Standard International Trade Classification Revision 3 (SITC Rev. 3) shown on Table 4. These products include raw food, animal skin, crude oil, chemical products, and manufactured products. Nigeria's total export to China in 2015 was US\$307.3 million, with the main export commodity being oil and lubricants, which represented US\$273.7 million. The next most important export in 2016 was crude materials which totaled US\$33.3 million. The remaining two broad commodities of cocoa and cotton exported to China in 2016 were valued between US\$o.I million and US\$0.2 million. Thus, in terms of Nigeria's exports to China, oil and lubricants ranked first, followed by beverages and live animals, while manufactured goods rank fourth. In terms of significance of Nigeria's exports to China relative to the world, Nigeria exported more crude materials than any other item, which constituted the main exports of Nigeria to China in 2016. 


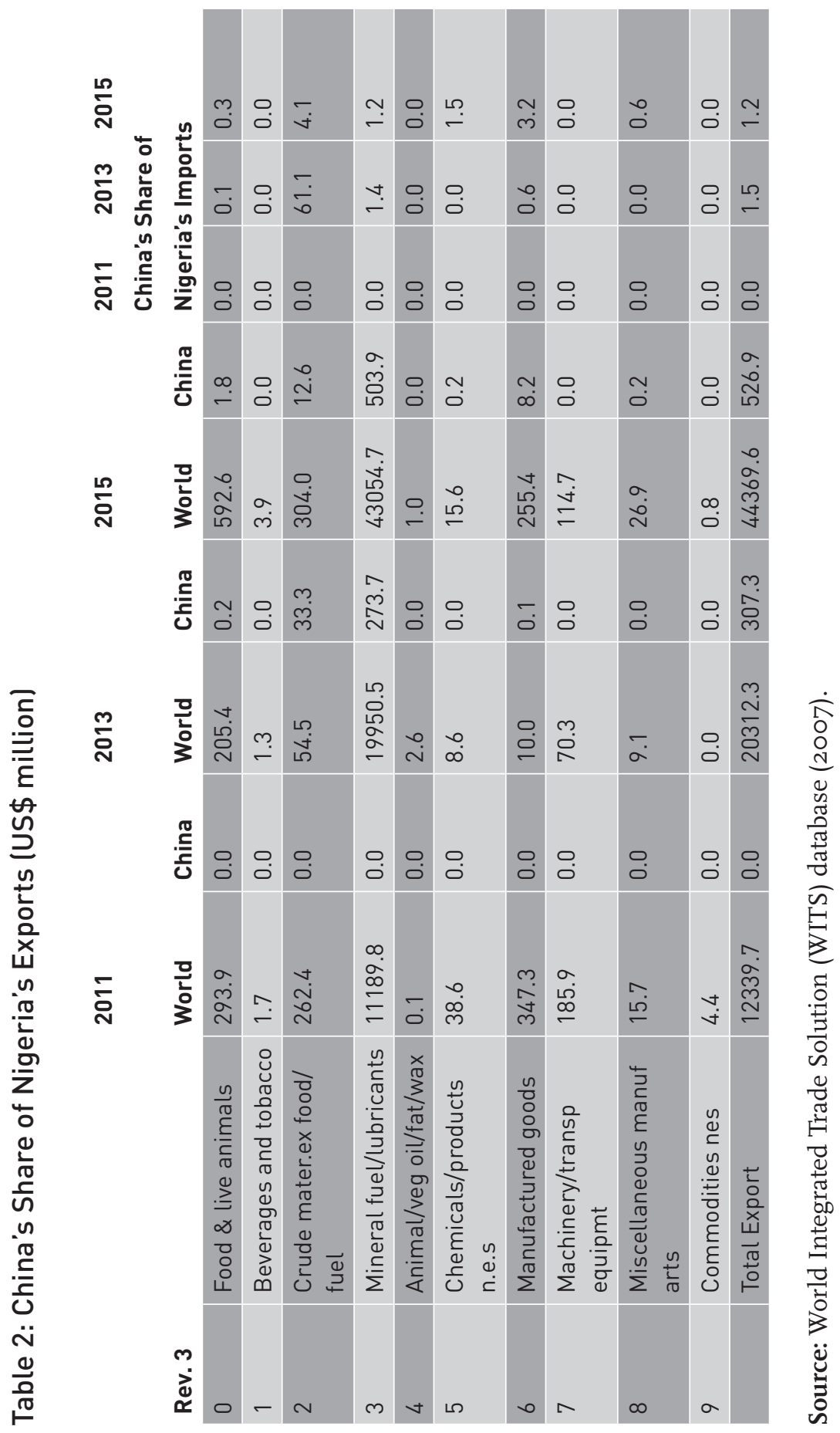




\section{Implications of Chinese Investments for Nigeria's Economic Security}

From the findings of this paper, Chinese investments in Nigeria are more pronounced in the oil, gas and road sectors. Other Chinese investment interests cover rail construction, power and telecommunications, with the SINOPEC, CNPC and CNOON being the major Chinese investors in the Nigerian oil and gas sectors with a total amount of about US\$713.4 billion investments as of 20I5. The Chinese investments in the construction sector in Nigeria, which is valued at about \$II5.4I billion, is dominated by 4 major companies; CCECC, CGC, SINOMA and CSCEC. The CCECC is into the construction of railways, housing, highway, bridges and housing, while the CGC is into construction of airports and water supply projects such as dams. SINOMA is into cement production while CSCEC is into building of real estate. The ZTE and Huwaei are the major companies in the Telecommunication sector which accounted for about USD55 billion in Chinese investments in 20I5. SEPCO is a major investor in the Nigerian power sector with about USD40.9 billion investments. The findings indicate that Chinese investments in the oil and gas sector have taken the lead over the years. Nigeria's exports to China include crude oil beverages, animal skin, arts materials, which total around \$I2 billion.

It can be deduced from the foregoing that Chinese investments in Nigeria are huge and on growing, while Nigeria's investment in China is far smaller, partly because of its inability to compete with Chinese products in China, thus undermining its economic security against China's dominance. Nigeria needs to build up its internal capacity to measure up to the competitive environment in China. Though, the magnitude of Chinese investments is large in Nigeria but its developmental contribution to the country is what remains questionable, as much of the gains made from its investment in Nigeria are not re-invested, but rather repatriated to China to further its economic growth, while undermining the survival of Nigeria's economy. Chinese investments in the oil and gas, power, telecommunication, and construction sectors have also increased Nigeria's reliance on China for its telecommunication gadgets instead of facilitating made-in-Nigeria ICTs, through technology transfer, leading to a lack of creativity and diversification of the Nigerian economy, and thus undermining its economic security under the aspect of self-reliance. The fact that the oil sector, which is the main stay of the Nigerian economy and from where the country earns 80 percent of its foreign trade, is mainly managed by foreigners, including Chinese, 
amount to undermining Nigeria's economic security because it gives them privileged access to information on the source of the relative success upon which Nigeria's oil economy is premised, and on how such economy could be compromised if need be.

The study found that Chinese investments have continued to expand in Nigeria, with increasing competition between local manufacturing industries and foreign investments in the country. All the above negative scenarios expose the Nigerian economy to the dangers of stunted growth and undermines its nascent industries because of strong competitors from China. There is also the dependency of the Nigerian economy on China, as 60 percent of Nigeria's electronic imports are currently from China, because those goods are relatively cheaper than those being imported from Europe. Many of the Nigerian middle range industries are unable to sell their products in the markets because of higher cost of production, high overhead cost and dilapidated production infrastructure in Nigeria, thus undermining the security of local companies from imminent collapse in the face of strong competition by imported goods from China. Corruption in Nigeria also undermines its economic security as many tax agencies in Nigeria, including the Federal Inland Revenue, sometimes undervalue the Chinese company taxes', thus leading to the loss of huge accruable revenue to Nigeria. Inhumane treatment of Nigerian workers in Chinese companies also undermines their personal economic security as many of them are disengaged without entitlement while others are overworked and underpaid.

Increased influx of Chinese business into Nigeria has largely pushed many nascent local industries out of business, leading to job loss and personal economic insecurity for those workers. In the Kano state for instance, the presence of Chinese textile companies has rendered many Nigerians jobless, because the company forced many local companies to close down, owing to the fact that they could not compete with the companies. Nigeria has also remained a huge market for Chinese products, which in turn has continued to boost China's economy rather than Nigeria's, thus weakening the latter's economic security. The Chinese Embassy in Nigeria also undermines its economic security, by mainly granting visas to Nigerians who want to import from China, which created the opportunity for many Nigerians to patronize relatively cheap Chinese products instead of the locally made, which led to the gradual collapse of local industries. Many Chinese companies, including ZTE, do not produce in Nigeria, as most of their products are imported from China with complete equipment and Chinese technicians, thus undermining job security for many Nigerians. 


\section{Conclusion}

Findings from this paper were that Nigeria and China have benefitted from their diplomatic relations but the relationship is not mutually rewarding, having been tilted towards China. The unequal relationship between the two countries has increased the dependency of the Nigerian economy on China and undermined its economic security. Findings also revealed that China is a global model of rapid socio-economic transformation, that Nigeria could study to enhance optimal performance for its economy. The study concluded that, for Nigeria to benefit optimally from its competitive economic relations with China, the country needs to build up its internal productive capacity through regular training of its workforce.

\section{Recommendations}

There should be a synergy between the Nigerian government and Sino-Nigerian stakeholders, to ensure coherence in strategizing policies and efforts aimed at bridging the trade imbalance between the two countries in favor of Nigeria. Nigeria should also diversify its exports from primary to secondary products to increase its product value in China, in order to generate higher foreign exchange earnings. Nigerian government should pass legislation against the import of inferior Chinese goods.

\section{REFERENCES}

Ampiah, Kweku, and Sanusha Naidu. 2008. "Crouching Tiger, Hidden Dragon?: Africa and China”,12-17. Cape Town: University of Kwazulu-Natal Press.

Brautigam, Deborah. 2009. The Dragon's Gift: The Real Sting of China in Africa. New York: Oxford Press.

Brown, D. 20I2. "Hidden Dragon Crouching Lion: How China's Advance in Africa is underestimated and Africa's Potential Underappreciated"; Strategic Studies Institute USA .

Chibundu, V. N. 2007. Foreign Policy with Particular Reference to Nigeria (1961-2008) . Spectrum books Limited Ibadan. 
Christensen, Thomas. 1996. "Useful Adversaries: Grand Strategy, Domestic Mobilization and Sino-American Conflict I947-I958," 43-45. Princeton: University Press.

Dabour, N. 2000. "The role of Foreign Direct Investment(FDI) in Development and growth in OIC member countries" Journal of Economic Cooperation 2I,(3) 27-55.

Davies, Martyn. 2008. “Special Economic Zones: China's Development Model comes to Africa". In China into African Trade and Influence, edited by Rotberg,Berga, I37-I45 Maryland: Brooking Institution Press.

Davies, P. 2007. China and the end of poverty in Africa - towards mutual benefit? Diakonia, August . Alfaprint, Sundbyberg, Sweden,

Denus, Tull. 2006. "China's Engagement in Africa: Scope, Significance and Consequences” The Journal of Modern African Studies. No.3. Vol.44 459-497.

Enuka, Chuka. 2010. "The Forum of China-Africa Cooperation (FOCAC): A Framework of the $2 \mathrm{I}^{\text {st }}$ Century". Pakistan Journal of Social Sciences (PJSS) 30 (2): 2009-2018.

Farole, T and Winkler D, eds. 20I4. "Making Foreign Direct Investment Work for Sub-Saharan Africa: Local Spillovers and Competitiveness in Global Value Chains". Directions in Development. Washington, DC: World Bank

Gregory, M. S. 200I. "Elephants, Ants And Superpower: Nigeria s Relations With China"; publication eds Chris Alden "Issues in the Nigerian - China Dialogue NIIA PESPECTIVE": South Africa Institute of International Affairs Occasional paper No 42 SAIIA'S On the Occasion of Nigeria - China Dialogue.

Global Development Monitoring Report. 2012: A Development Emergency in China, II-I3. Washington: Global Press.

Haruna Danja, K. 20I2. "Foreign Direct Investment and the Nigerian Econo$m y^{\prime \prime}$ in American

Hickey, M. and Mohan G. 2004. Towards participation and transformation: critical themes and challenges. London: Macmillan Press

Hyden, G. and Mukandala R. (eds.) (I999). Agencies in Foreign Aid: Comparing China, Sweden and the United States in Tanzania. London: Macmillan Press

Ian, Taylor. 2006. China's Oil Diplomacy in Africa. London: Routledge. 
Jiang, Wenran. 2009. “Fuelling the Dragon: China's Rise and its Energy and Resources Extraction in Africa”. China's Quarterly (I99) (09): 585-6I5.

Kelley, J. 20I0. "China in Africa: Curing the Resource Curse with Infrastructure and Modernization." Sustainable Development Law \& Policy NewYork I2, no. 3 35-4I, 57-60.

Kort, Daniel. 20I0. South- South Strategic Bases for Africa to Engage China. London: Zed Books

Meine, Park. 20II. The New Presence of China in Africa. Amsterdam: University Press.

Mthembu, Salter .G. 2009. "Elephants, Ants and Super Powers: Nigeria's Relations with China". South African Institute of International Affairs, 7-I3.

Ogunrinu, Olaoluwanike. 20I4. "Chinese Investments in the Nigerian Oil, Gas and Power Sectors". Graduate Project. University of Ilorin: Department of History and International Studies, 6-34.

. 20I7. "The Implications of Chinese Investments in Nigeria for National Development”. Postgraduate Dessertation. Centre for Peace and Strategic Studies, University of Ilorin, 9-16.

Ogunsanwo, Alaba.2008. China's Policy in Africa, 23-28. London: Cambridge University Press.

Okwe, Mathias. 20I2. "Federal Government Incurs More Debt, Takes China's \#.. billion Credit”. The Guardian, 9.

Oniku, Charles, and Gbadamosi, Adelodun. 2009. "The Strategic Implications of China's Economic Pacts with Sub-Saharan African Countries: The Case of Nigeria". Conference of the International Journal of Arts and Sciences I(I8):II5-I3O

Pease, Kelley-Kafe. 20I0. "China in Africa: Curing the Resource Curse with Infrastructure and Modernization". Sustainable Development Law and Policy. I2(3). 35-4I, 57-60.

Reno, William. I999. “The Descriptive Political Logic of Weak States”. In Warlord Politics and African States, edited by Edbong Moore 23-28. Lynne: Rienner publication. 


\begin{abstract}
In spite of functional bilateral relations existing between Nigeria and China, the benefits accrued by each country through their socio-economic interaction have attracted debate, resentment and critique among Nigerians. Concerns have been raised over presumed negative impact of Chinese investments on Nigeria's fragile economy through the dumping of inferior Chinese industrial products in the country and lack of technology transfer from China to Nigeria. Some scholars argued that there are fewer opportunities for the survival of Nigeria investments in China, because of the employment and visa restrictions many Nigerians face to explore business opportunities in China. This study examined China's investment profile in Nigeria and its implications for the latter's economic security. Specifically, the paper traced the background of the Nigeria-China relations and investigated the main thrusts and strategic importance of the relationship. The study also identified the key sectors of Chinese investments in the Nigerian Economy and discussed the implications of Nigeria-China bilateral relations for the economic survival of Nigeria. The study is anchored on descriptive research methodology, consisting of qualitative data, which relied primarily on the existing literature. Findings from the paper were that Nigeria and China have benefitted from their diplomatic relations but the relationship is not mutually rewarding having been tilted towards China. The unequal relationship between the two countries has increased the dependency of the Nigerian economy on China and undermined its economic security. Findings also revealed that China is a global model of rapid socio-economic transformation that Nigeria could study to optimize the performance of its economy. The study concluded that for Nigeria to benefit optimally from its competitive economic relations with China, the country need to build its internal productive capacity through regular training of its workforce. The Nigerian government should also ban the importation of substandard goods from China.
\end{abstract}

\title{
KEYWORDS
}

Investment; Economy; Security; Implications

Received on October 10, 2018.

Approved on January 13, 2019. 